\title{
Biodiversity studies on macro fungi with special reference to order agaricales: Indian scenario
}

\begin{abstract}
Studies on taxonomy and biodiversity of macro fungi (Agaricales) are securing more importance as many macrofungi are becoming extinct or facing the threat of extinction. Biodiversiy of macro fungi is important for ecosystem functioning and stability. Among variety of living creatures very less attention has been given to conservation of fungal biodiversity. They have a high nutritional value, due to good quality proteins. Out of 60,000 species of fungi, described throughout world, 10,000 species are fleshy macro fungi or mushrooms. Current review is an attempt to give a broad picture of the biodiversity of a particular group of fungi, viz. members of order Agaricales in India
\end{abstract}

Keywords: agaricales, biodiversity, ecosystem, taxonomy

\author{
Volume 5 Issue 6 - 2017 \\ Sandhya Dwivedi,' Surendra Singh,' Chauhan \\ UK, ${ }^{2}$ Mahendra Kumar Tiwari ${ }^{3}$ \\ 'Department of Post Graduate Studies and Research in \\ Biological Science, Rani Durgawati University India \\ ${ }^{2} \mathrm{~S} c h o o l$ of Environmental Biology and Biotechnology, Awadhesh \\ Pratap Singh University, India \\ ${ }^{3}$ Department of Environmental Science, AKS University, India
}

\begin{abstract}
Correspondence: Sandhya Dwivedi, Department of Post Graduate Studies and Research in Biological Science, Rani Durgawati. University Jabalpur, India, Tel +918989470720; Email sandhyabiotech2005@gmail.com
\end{abstract}

Received: November 02, 2017 | Published: December 14 2017

\section{Introduction}

Biodiversity includes not only many species that exist, but also the diversity of populations that makeup a species, the genetic diversity among individual life forms, and the many different habitats and ecosystem around the globe. ${ }^{1}$ Macrofungi are important economically due to their importance in food, medicine, bio-control, chemical, biological and other industries. ${ }^{2}$ Although the macrofungi are an integral part of a given ecosystem, their diversity and types are poorly studied, with a particular knowledge gap in the tropical regions including India. ${ }^{3}$ Macro fungi are diverse in their uses as food and medicine and several species serve as decomposers and also form mycorrhizal associations. ${ }^{4}$ Taxonomists describe about 1lakh species of fungi, but till now the fungal global biodiversity is not fully understood..$^{5}$ About 1.5 million fungi have been projected on earth surface. ${ }^{6}$ Of these, approx $5-7 \%$ of the fungi are described till now. ${ }^{7,8}$ Agaricales are considered cosmopolitan fungi. They grow easily in a wide variety of habitats, from the Artic to the Tropics. While some are limited to specific areas, others grow in geographically dispersed areas. In ecologically defined areas, mushrooms have preferences for specific substrates. The wide variety of habitats colonized by these fungi and substrates they extract from the soil shows that Agaricales order includes saprophytic, symbiotic, and parasitic species. Chemical substances existing in mushrooms may change according to the soil and climate of the region in which they grow. Knowledge of Agaricales morphology is fundamentally important in the taxonomy of these basidiomycetes and for understanding their physiological and phylogenetic aspects. Morphology is studied at four levels: macroscopic, microscopic, ultra-structure, and molecular biology. The order Agaricales comprises of 3 sub-orders, 17 families, 230 genera and approximately 5000 species, systematic study of the members of Agaricales were neglected in India as compared to other groups of fungi. They are an integral component of nutrient and elemental cycling of the global ecosystem. Immunomodulatory, antitumor, and antiproliferative effects of lectin isolated from various types of Agaricaceae mushrooms have been demonstrated by Zhao \& Priyamvada ${ }^{9,10}$ worked on Terrestrial Macrofungal Diversity in
Tropical Dry Evergreen Biome of Southern India and Its Potential Role in Aerobiology.

\section{Taxonomic studies on agaricales}

There are many Indian mycologist ${ }^{11-16}$ who have reported many species of family Agaricaceae, mostly represented by genus Agaricus from different states of India. These were some of the Indian mycologists who have recorded many species of Agaricaceae family mostly represented by Agaricus species ${ }^{17}$ initiated a series of entitled "South Indian Agaricales" and reported 230 Agaric and Bolete species in detail belonging to 67 genera from southern Indian states. He has excluded Kerela. From a survey of mushrooms in the North West Himalayas, Sharma $\mathrm{R}^{16}$ recorded 300 agarics belonging 15 families of Agaricales under 59 genera and 300 species. Purkayastha RP ${ }^{18}$ given detailed description of four species of Agaricus which were $A$. arvensis, A. campestris, A. sylvaticus, and A. trisulphuratus from West Bengal. Doshi ${ }^{19}$ reported A. abruptus, A. arvensis, A. campestris, A. bisporus, A. bitorquis, A. placomyces, A. silvaticus and A. silvicola from Rajasthan. In India, there are a number of studies on mushroom diversity especially on Amanitaceae and Russulaceae done by several workers. ${ }^{20,21}$ lakhanpal $\mathrm{TN}^{22}$ recorded 11 species of edible macrofungi from the upper hilly region of Shimla. Dhamodharan et al., ${ }^{23}$ have performed various experiments on medicinal properties of Agaricus bisporus which indicates that uncooked A. bisporus, with some edible mushrooms have small amounts of cancer causing hydrazine derivatives, including agaritine and gyromitrin. Das ${ }^{24}$ studied Diversity and conservation of wild mushrooms in Sikkim with special reference to Barsey Rhododendron Sanctuary. Kumar et al., ${ }^{25}$ performed the ethnomycological survey in Jammu and Kashmir. Pushpa et al. ${ }^{26}$ studied the biodiversity of mushrooms belonging to the class Basidiomycetes in Bangalore. Anand et al., ${ }^{27}$ have given first report on five unreported macrofungi from Rajouri district of Jammu and Kashmir ( $\mathrm{J}$ and $\mathrm{K}$ ). Senthilarasu ${ }^{28}$ has studied diversity of agarics (gilled mushrooms) of Maharashtra. Review of Literature revealed that most of the records on Termitomyces has been made in Kerala State. Farook et al., ${ }^{29}$ having a total of 15 species, followed 
by 10 species from Goa and 9 species from Karnataka. From Tamil Nadu and Maharashtra they reported 2 and 3 species; respectively. Kumar et al., ${ }^{30}$ performed studies on Macro-fungal diversity and nutritional importance of some edible mushrooms of Nagaland. A new variety of Rhodocybe popinalis (Entolomataceae, Agaricales) from coprophilous habitats was reported by Kaur et al. ${ }^{31} \&$ Khaund et al., ${ }^{32}$ studied the wild edible macrofungal species consumed by the Khasi tribe of Meghalaya. Later Khaund et al., ${ }^{33}$ investigated amylase, cellulase, and protease, tyrosinase, and laccase enzymes of the macrofungi. Anand et al., ${ }^{27}$ studied the macrofungal diversity of Rajouri District of Jammu and Kashmir and identified mushroom up to species level which belongs to 14 orders, 31 families, 67 genera. 8 species were recorded for the first time in India. Agaricales dominated by $47 \% .^{34}$

\section{Macrofungal diversity studies in India:}

Many mycologists have given significant contributions in study of macro fungal diversity in India; some of these mycologists are ${ }^{31,35-41}$ worked on mushroom biodiversity especially for agarics from Nilgiri Biosphere Reserve, Western Ghats. Kaur ${ }^{42} \&$ Kumar et al. ${ }^{43}$ reported 92 species of genus Lepiota ${ }^{44-46}$ have very important contributions in the study of mushroom diversity. From Jammu and Kashmir, North West India, Orissa and Kerala many species of Leucocoprinus were documented and described by many mycologist. ${ }^{47}$ A large number of agarics which includes species of Lepiota, Leucocoprinus and Macrolepiota were reported by Butler et al. ${ }^{48}$ \& Bilgrami et al., ${ }^{49}$ in Fungi of India. From West Bengal ${ }^{50}$ documented Leucocoprinus meleagris. From Chennai ${ }^{44}$ have also described 14 species and 2 new varieties of Lepiota ${ }^{51}$ also recorded and described 5 taxa which were new record to India, including Lepiota vindicta. Total six species of Lepiota have been published by Atri NS. ${ }^{46}$ Out of these six species, two were new varieties and three were first time reported from India. Atri et al., ${ }^{46}$ provided detailed information regarding mushroom systematics for those who are beginners and gave a taxonomic account of six species of Lepiota collected from Punjab. Kumar ${ }^{43}$ recorded one new species of Leucocoprinus from state Kerla. He described the detail information about this species. Kumar ${ }^{43}$ also documented twenty-two taxa belonging to the agaric genus Lepiota from Kerala, including eight new species recorded first time in India and one new variety, namely L. ananya, L. anupama, babruka, L. babruzalka, L. harithaka, L. nirupama, L. shveta, L. zalkavritha and L. brevipesvar. Among different edible wild macrofungi 5 species viz. Volveriella volvacea, Agaricus semotus, Lentinus polychrous, Stropharia semiglobata and Termitomyces eurrhizus were commonly occurred which were belonging to family Plutaceae, Agaracaceae, Lentinaceae, Strophariaceae and Tricholomataceae. Their morphological characters were discussed along with the traditional method of recipe preparation by the said ethnic community. Study of potential utilization of tribal mushrooms of Madhya Pradesh by tribals was done by Rahi ${ }^{52} \&$ Rajak et al., ${ }^{53}$ worked on edible tribal mushroom resources of Central India and their ethnological aspects. Sharma ${ }^{54}$ studied the taxonomy of some of the wild mushrooms (Ectomycorhiza) of Jabalpur.

Karwa $^{55}$ reported total of 153 species of edible and medicinal mushrooms in the study conducted in Melghat forest, which is a Tiger Reserve situated in Satpuda mountain ranges in Maharashtra State. Species dominating belong to genera Agaricus, Pleurotus, Termitomyces, Cantharellus, Ganoderma, Auricularia sp., Schizophyllum, Morchella, etc. The biotechnological application of these important mushrooms is needed to be exploited. These studies will open new avenues in improvement of breeding programs of commercially cultivated mushroom species.

Senthilarasu et al., ${ }^{56}$ is the mycologist who studied morphological taxonomy of 15 agaric species belonging to order Agaricales collected from dipterocarp forests of Western Ghats of Karnataka. They briefly described their geographic distribution in India. They reported 132 species in 60 genera belonging to Agaricales, Polyporales and Russulales. Basumatary et al. ${ }^{57}$ reported uses of wild edible macrofungi by Bodo community of Kokrajhar district, Assam. Senthilarasu et al., ${ }^{56}$ reported morpho-taxonomy of 15 agaric species belonging to Agaricales collected from dipterocarp forests of Western Ghats of Karnataka and reported 132 species in 60 genera belonging to Agaricales, Polyporales and Russulales. Biodiversity studies conducted in different parts of Central India by several workers. (Study suggests that forest of Central India is rich in medicinal (Lentinus sp, Pleurotus sp, Shyzophyllum sp, Pisolithus sp Ganoderma lucidum) and edible mushroom (Agaricus bisporus, A. campestris., Pleurotus sp., Termitomyces heimii). Study revealed that this region is dominating mainly by families of order Agaricales. ${ }^{58-61}$

\section{Conclusion}

This rich macrofungal diversity of forest region needs further exploration to widen the nutritional and medicinal base of the rural population who depend on the mushrooms through conservation, cultivation and commercialization activities. The rich diversity of mushrooms offers huge socio-economic potentials. However, they need to be properly documented for optimum application The biggest threats to biodiversity are habitat fragmentation and degradation, the introduction of non-native species, overexploitation, pollution and disease. Climate change is also increasingly being considered as a threat to diversity of species. The leading cause that can lead to extinction is thought to be human activity. Effective methods should implement to stop genetic erosion and encourage the rehabilitation of degraded ecosystem in mega biodiversity regions. Efforts are initiating to protect and save biodiversity both by ex-situ and in-situ conservation. There are number of edible fungi that are still being collected from the forest for human consumption and research is required to domesticate new species. There is a need for developing superior strains of cultivated mushrooms using available germplasm. Alternatively systems have to be developed for commercial/industrial scale mycelia multiplication for extracting industrial/ medicinal important metabolites/compounds. Amongst the vast number of living forms very little attention has been paid to conservation of fungal biodiversity. Many fungal species are on threat due to loss of natural habitats, soil and air pollution, expansion of mono-cropping and loss of genetic diversity. For the smooth functioning of this terrestrial ecosystem, the conservation of mushroom diversity is critical. Keeping in view this enormous mushroom treasure it is the high time to fully conserve this biodiversity. And hence a timely research regarding isolation, identification and characterization of the existing mushroom flora is essential. Biotechnological tools can be employed in order to achieve the in situ and ex situ conservation of many of the mushroom species.

\section{Acknowledgements}

None.

\section{Conflict of interest}

The author declares no conflict of interest. 


\section{References}

1. Ananthakrishnan TN. Insect Biodiversity and conservation with special reference to natural forest litter Ecosystems. Oxford and IBH publishing Co Pvt Ltd; 1997. 1(5):307-316.

2. Manoharachary C, Sridhar K, Singh R, et al. Fungal biodiversity: Distribution, conservation and prospecting of fungi from India. Curr Sci. 2005;89(1):58-71.

3. Lakhanpal TN. Mushroom Biodiversity in India: Prospects and Potential. Proceedings of the 8th International Conference on Mushroom Biology and Mushroom Products (ICMBMP8), 2014. p. 7-16.

4. Kinge RT, Nkengmo AA, Theobald MN, et al. Species Richness and Traditional Knowledge of Macro fungi (Mushrooms) in the Awing Forest Reserve and Communities, Northwest Region, Cameroon. Journal of Mycology. 2017;2017:9.

5. Mueller GM, Schmit JP. Fungal biodiversity: What do we know? What can be predict? Biodiversity and conservation. 2006;16(1):1-5.

6. Hawksworth DL. The fungal dimension of biodiversity: magnitude, significance and conservation. Mycological Research. 1991;95(6):641655 .

7. Hawksworth DL. Fungal diversity and its Implifications for Genetic Resource collections. Studies in Mycology. 2004;50:9-18.

8. Rossman AY. A strategy for an all-taxa inventory of fungal biodiversity. In Biodiversity and Terrestrial Ecosystems Taipei: Academia Sinica Monograph Series. 1994;14:69-94.

9. Zhao C, Sun H, Tong X, et al. An antitumour lectin from the edible mushroom Agrocybe aegerita. Biochem J. 2003;374(Pt 2):321-327.

10. Priyamvada H, Akila M, Singh RK, et al. Terrestrial Macrofungal Diversity from the Tropical Dry Evergreen Biome of Southern India and Its Potential Role in Aerobiology. PLOS One. 2017;12(1):e0169333.

11. Pegler DN. A preliminary Agaric flora of East Africa. Kew Bulletin Additional Series, 1977. 6:1-615.

12. Sathe AV, Rahalkar SR. Agaricales from South India-I. Biovigyanam 1978;5:125-130.

13. Sathe AV, Deshpande S. Agaricales of Maharashtra. Advances in Mycology and Plant Pathology. India: Oxford and IBH Publishing Co; 1979. p. 82-88.

14. Sathe AV. Agaricology in India - A review of work on Indian Agricales. Biovigyanam. 1979;5:125-130.

15. Sathe AV, Kulkarni SM. A check list of wild edible mushrooms from South West India. India: Indian Mushroom Science, II Regional Research laboratory; 1987. p. 411-413.

16. Sharma R, Rajak RC, Pandey AK. Evidence of antagonistic interactions between rhizosphere and mycorrhizal fungi associated with Dendrocalamus strictus (Bamboo). Journal of Yeast and Fungal Research. 2009;1(7):112-117.

17. Natarajan K. Mushroom Flora of South India (except Kerala). India: Malhotra Publishing House; 1995. p. 375-386.

18. Purkayastha RP, Chandra A. A new technique for in-vitro production of Calocybe indica an edible mushroom from India. The mushroom journal. 1976;40:1-2.

19. Doshi A, Sharma SS. Wild Mushroom of Rajasthan, in: Advances in Mushroom Biology and Production. India: Proceeding of Indian Mushroom Conference, MSI, NCMRT; 1997. p. 105-127.

20. Bhatt RP, Tulloss RE, Semwel KC, et al. Amanitaceae reported from India. A critically annotated checklist. Mycotaxon. 2003;88:249-270.
21. Das K, Sharma JK. Russulaceae of Kumaon Himalaya Botanical Survey of India. India: Ministry of Environment and Forests, Government of India; 2005. p. 1-255.

22. Lakhanpal TN. Mushroom flora of North West Himalaya. In: Chandha KL, Sharma SR, editors. Advances in Horticulture Mushroom. India: Malhotra Publication House; 1995. 13:351-373.

23. Dhamodharan G, Mirunalini S. A Novel Medicinal Characterization of Agaricus bisporus (White Button Mushroom). Pharmacology. 2010;2:456-463.

24. Das K. Diversity and conservation of wild mushrooms in Sikkim with special reference to Barsey Rhododendron Sanctuary. NeBIO An International Journal of Environment and Biodiversity. 2010;1(2):1-13.

25. Kumar S, Sharma YP. Diversity of Wild Mushrooms from Jammu and Kashmir (India). Proceedings of the 7th International Conference on Mushroom Biology and Mushroom Products (ICMBMP7) Section: Economical and societal features, 2011. p. 568-577.

26. Pushpa H, Purushothama KB. Biodiversity of mushrooms in and around Bangalore (Karnataka), India. American-Eurasian Journal of Agriculture \& Environmental Science. 2012;12(96):750-759.

27. Anand N, Chowdhry PN. First report on five hitherto unreported macro fungi from Rajouri district of Jammu \& Kashmir, India. Annals of Biological Research. 2013;4(5):62-70.

28. Senthilarasu G. Diversity of agarics (gilled mushrooms) of Maharashtra, India. Current Research in Environmental \& Applied Mycology. 2014;4(1):58-78.

29. Farook VA, Khan SS, Manimohan P. A checklist of Agarics (gilled mushrooms) of Kerala State, India. Mycosphere. 2013;4:97-131.

30. Kumar R, Tapwal A, Pandey S, et al. Macro-fungal diversity and nutrient content of some edible mushrooms of Nagaland, India. Nusantara Bioscience. 2013;5(1):1-7.

31. Kaur A, Atri NS, Kaur M. A new variety of Rhodocybe popinalis (Entolomataceae, Agaricales) from coprophilous habitats of India. Journal on New Biological Reports. 2013;2(3):260-263.

32. Khaund P, Joshi SR. Wild edible macrofungal species consumed by the Khasi tribe of Meghalaya, India. Indian Journal of Natural Products and Resources. 2013;4(2):197-204.

33. Khaund P, Joshi SR. Enzymatic profiling of wild edible mushrooms consumed by the ethnic tribes of India. Journal of Korean Society Applied Biology Chemistry. 2014;57(2):263-271.

34. Berkley MJ. Decades of Fungi, Decas 1-62, Nos. 1-620. In:Hooker's London. Journal of Botany. 1856;3(8):1844-1856.

35. Berkeley MJ. Fungi of the plains of India. Intellectual Observer. $1867 ; 12: 18-21$.

36. Sathe AV, Rahalkar SR. Agaricales from South West India II. Indian Journal of Mushrooms. 1976;2:77-80.

37. Sathe AV, Rahalkar SR. Agaricales from South West India. Biovigyanam 1978;3:119-121.

38. Sathe AV, Sasangan KC. Agaricales from South West India-III Biovigyanam. 1977;3:119-121.

39. Sarwal BM, Rawla GS. Taxonomic studies on Indian Agarics-III. Bibliotheca Mycologica. 1983;91:541-548.

40. Purkayastha RP, Chandra A. New species of edible mushroom from India. Transactions of the British Mycological Society. 1974;62(2):415-418.

41. Natarajan K, Kumaresan V, Narayanan K. A checklist of Indian agarics and boletes (1984-2002). Kavaka. 2005;33:61-128. 
42. Kaur A. Mushroom flora of Patiala and its surrounding areas. India: Ph.D. Thesis submitted to Punjabi University; 2000. p. 1-309.

43. Kumar TKA, Manimohan P. The genus Lepiota (Agaricales, Basidiomycota) in Kerala state, India. Mycotaxon. 2009;107:105-138.

44. Natarajan K, Manjula B. South Indian Agaricales XII Lepiota. Bibliotheca Mycology. 1983;91:568-681.

45. Sarwal BM. Taxonomic studies on Indian Agarics-II B. Indian Phytopathology. 1984;37(2):228-233.

46. Atri NS, Saini SS. Collection and study of Agarics- An introduction Indian Journal of Mushrooms. 2000;18(1 and 2):1-5.

47. Abraham SP, Kaul TN. Larger fungi from Kashmir III. Kavaka. 1985;13(2):77-81.

48. Butler EJ, Bisby GR. The fungi of India. Imp. Coun. Of Agr. Res. India. Science Mono I. 1931;18:1-233.

49. Bilgrami KS, Jamaluddin S, Rizwi AM. Fungi of India. India: Today and Tomorrow's, Printers and Publishers; 1991. p. 1-798.

50. Mondel T, Purkayastha RP. New additions to Indian edible fungi. Indian Phytopathology. 1983;36(4):736-738.

51. Manimohan P, Leelavathy KM. New agaric taxa from southern India. Trans. British Mycological Society. 1988;91(4):573-576.

52. Rahi DK. Cultivation of wild mushrooms of Central India, using different agrowastes. India: Ph.D. thesis, Rani Durgawati University; 2002. p. 33-45.

53. Rajak RC, Rai MK. Edible Tribal Mushroom Resources of Central India and Their Ethnological Aspects. International Journal of Medicinal Mushrooms. 2005;7:1-458.
54. Sharma R. India: Ph.D. Thesis, Department of Biological Science, Rani Durgavati University; 2007. p. 138-145.

55. Karwa A, Rai MK. Tapping into the edible fungi biodiversity of Central India. Biodiversitas. 2010;11(2):97-101.

56. Senthilarasu G, Kumaresan V. Diversity of agaric mycota of Western Ghats of Karnataka, India. Current Research in Environmental \& Applied Mycology. 2016;6(2):75-101.

57. Basumatary M, Gogoi M. Uses of wild edible macro fungi by Bodo community of Kokrajhar district, Assam, India. Tropical Plant Research. 2016;3(1):176-181.

58. Dwivedi S, Singh S, Chauhan UK, et al. Study of frequency, density, abundance and diversity of wild mushrooms of tropical mixed forest of Central India. International Journal of Applied Research and Tehnology. 2017;2(2):136-139.

59. Singh S, Dwivedi S, Chauhan UK, et al. Ecological Diversity and Distribution of Noble Macro Fungi of Sal Dominated Forest of Central India with Special Reference to Agaricales. International Journal Of Biotech trends and Technology. 2015;13(I):7.

60. Singh S, Dwivedi S, Chauhan UK, et al. First report on unreported macro fungi from Rewa district of Vindhyan Region, India. International Research Journal Of Environmental Sciences. 2015;4(8):50-59.

61. Sandhya D, Mahendra KT, Chauhan UK, et al. Biodiversity of Mushrooms of Amarkantak Biosphere Reserve Forest of Central India) International Journal of Pharmacy and Life Science. 2012;3(1-2):5. 